\title{
Dystopian Literature and the Sociological Imagination
}

\section{Sean Seeger (Essex) and Daniel Davison-Vecchione (Cambridge)}

\begin{abstract}
This article argues that sociologists would benefit from taking dystopian literature seriously. This is because (i) the speculation in dystopian literature tends to be more grounded in empirical social reality than in the case of utopian literature, and (ii) the literary conventions of the dystopia more readily illustrate the relationship between the inner life of the individual and the greater whole of social-historical reality. These conventional features make dystopian literature especially attuned to how historicallyconditioned social forces shape the inner life and personal experience of the individual, and how acts of individuals can, in turn, shape the social structures in which they are situated. In other words, dystopian literature is a potent exercise of what C Wright Mills famously termed 'the sociological imagination'.
\end{abstract}

Key words: sociology, imagination, speculative literature, dystopia, utopia

\section{Sociology and speculative literature}

Social thinkers have begun to return to the role of speculative literature in the sociological enterprise. One can call this a 'return' because, thanks to the efforts of such scholars as Ruth Levitas and Krishan Kumar, we more keenly appreciate why HG Wells saw 'the creation of Utopias - and their exhaustive criticism - [as] the proper and distinctive method of sociology' (Wells, 1907: 367). For Wells, sociology should not take the natural sciences - with their grounding in the observation and classification of facts to formulate testable, general laws - as the paradigm for its own mode of enquiry. Rather, the imagination, of the kind on display in imaginative literature, makes a valuable contribution to understanding and thinking critically about society.

To understand what Wells took this contribution to be, one must consider his broader, anti-positivistic vision of sociology as an enterprise that inescapably evaluates and prescribes, even if it frequently does so implicitly rather than explicitly. In his own words, '[t]here is no such thing in sociology as dispassionately considering what is, without considering what is intended to be' (Wells, 1907: 366-67). Accordingly, sociology always has an imaginative component, which Wells understood as putting forward an ideal view of society against which one can measure the present. Wells 
arrives at this conclusion primarily because one cannot isolate, observe, and compare societies from an extrasocietal vantage point. One can compare different societies or communities with one another, as often occurs in self-described comparative studies within the empirical social sciences, but to Wells, such comparisons are of limited value because the isolation and unity of a given society or community are necessarily artificial. Such 'alleged units have as much individuality as pieces of cloud; they come, they go, they fuse and separate' (Wells, 1907: 364).

Accordingly, Wells saw two kinds of endeavour as 'valid sociological work'. First, there is the 'social side of history', including the kind of historical literature that attempts 'to impose upon the vast confusions of the past a scheme of interpretation, valuable just in the value of its literary value, of the success with which the discrepant masses have been fused and cast into the shape the insight of the writer has determined' (Wells, 1907: 365-66) To Wells, such endeavours 'restore the dead bones of the past to a living participation in our lives' (Wells, 1907: 366). Second, there is 'the description of the Ideal Society and its relation to existing societies' (Wells, 1907: 367).

One should bear in mind that Wells derived this second understanding of sociological work from his notion of a single, grand, and complex 'Social Idea' that struggles to realise itself throughout the history of civilisation, hence his vision of a single book summarising the 'perfect state', institutions of which would serve as a benchmark for the institutions of existing states (Wells, 1907: 367-68). Additionally, one should remember that Wells saw the two veins of sociological work he identified as mutually complementary aspects of the same enterprise. The 'historical' part of sociological work effectively amounts to 'a history of the suggestions in circumstance and experience of that Idea of Society' of which the 'utopian' part consists, and 'of the instructive failures in attempting [the Idea of Society's] incomplete realisation' (Wells, 1907: 369). Whether approached from the historical or utopian direction, then, the sociological enterprise rests upon visions of society produced by the human imagination.

As such, Wells features heavily in reassessments of the role of the speculative - in the sense of any application of the imagination to the future - in sociological scholarship. For instance, Kumar finds in Wells's precepts and practice two promising directions for modern sociology. On the one hand, there is a Platonic mode that 'encourages us frankly to construct utopias' and to prepare for their future implementation; on the other hand, there is an Aristotelian mode that examines and reassesses the foundations of utopian accounts, as well as the accounts themselves (Kumar, 1990: 212-23). Similarly, Levitas calls for a sociology that embraces a more utopian method, which she terms the Imaginary Reconstitution of Society (IROS). According to this method, sociology would have an 'archaeological' mode that excavates 'from political discourse the underpinning model of the good society', an 'architectural' mode that holistically models 'the collective alternatives open to us', and an 'ontological' mode that helps us to imagine ourselves otherwise (Levitas, 2010: 543-44). More recently, Duncan Bell has argued that Wells's utopian vision of sociology was shaped by a form of philosophical pragmatism, with Wells viewing 'sociology as a fertile imaginarium, a source of ideas about how to radically improve society through understanding the historical development of a sense of 
collective consciousness, envisioning alternative futures, and motivating people to act on such visions' (Bell, 2017: 53).

Nevertheless, as the foregoing examples serve to illustrate, such reassessments of the speculative in sociology have focussed almost exclusively on the potential applications of utopia as both an analytic category and a literary genre. The potential applications of dystopia, meanwhile, remain curiously under-examined. These potential applications become especially significant in light of what $\mathrm{C}$. Wright Mills famously identified as the faculty upon which sociological knowledge depends: the 'sociological imagination'. In Mills' words, the sociological imagination is what 'enables us to grasp history and biography and the relations between the two within society' (Mills, 2000: 6). In other words, the sociological imagination is the quality of mind that allows one to imagine how historically-conditioned social forces shape the inner life and personal experience of the individual, and how acts of individuals can, in turn, shape the social structures in which they are situated.

In Mills' view, this ability to 'grasp the interplay of man ( $\mathrm{sic}$ ) and society, of biography and history, of self and world' is essential to allowing the individual to 'understand his ( $\mathrm{sic}$ ) own experience and gauge his own fate' (Mills, 2000: 4-5). The individual achieves this 'only by locating himself within his period' and 'by becoming aware of those [possibilities and opportunities] of all individuals in his circumstances' (Mills, 2000: 5). By envisaging the connections between biography and history in this manner, one becomes able to see the intersection between 'the personal troubles of milieu' and 'the public issues of social structure' (Mills, 2000: 8). By 'troubles', Mills meant private matters that 'have to do with [the individual's] self and with those limited areas of social life of which he is directly and personally aware' (Mills, 2000: 8). By 'issues', Mills meant public matters that 'have to do with the organization of many such [individual] milieux ( $\mathrm{sic}$ ) into the institutions of society as a whole, with the ways in which various milieux overlap and interpenetrate to form the larger structure of social and historical life' (Mills, 2000: 8). In other words, 'troubles' correspond to 'biography' and 'issues' to 'history'.

The sociological imagination helps people 'to use information and to develop reason in order to achieve lucid summations of what is going on in the world and of what may be happening within themselves' (Mills, 2000: 5). There are two key dimensions to Mills' virtual erasure of the private/public distinction in his vision of the sociological enterprise. First, the intersection between the private and the public is 'one of constant flow' because private troubles become public issues and public issues cause private troubles (Brewer, 2005: 662). As such, the primary concern of sociology as a discipline is the 'study of individuals within their social structural context', which entails appreciating 'the mutual embeddedness of individuals and society' (Brewer, 2005: 662). Second, Mills believed that sociologists have a public responsibility to the rest of society by addressing people's private troubles. In his view, sociology 'should be employed publicly in a manner to erode any false separation between people's private lives and the public realm' (Brewer, 2005: 662). 
Importantly for present purposes, Mills understood the sociological imagination as helping us grasp and understand 'the human variety', 'which consists of all the social worlds in which men have lived, are living, and might live' (Mills, 2000: 132) (emphasis added). This strongly suggests that, although Mills does not elaborate on the role of the speculative in sociology, in his view speculative literature can be a legitimate object of sociological investigation or - even more provocatively - a legitimate form of sociological thought. This in turn suggests that, while Mills saw the sociological imagination as fundamental to sociology as a discipline, he did not view this imagination or its insights as the province of professional sociologists alone.

Despite these implications, there is an evident tension or ambivalence in how Mills approaches speculative literature, including dystopian fiction. On the one hand, Mills observes that people often want to know 'social and historical reality', but 'do not find contemporary literature an adequate means for knowing it' (Mills, 2000: 17). Indeed, Mills goes on to state that, even though art often formulates private troubles and public issues, and expresses yearnings for 'a "big picture" in which [people] can believe and within which they can understand themselves', nevertheless '[a]rt does not and cannot formulate these feelings as problems containing the troubles and issues men must now confront if they are to overcome their uneasiness and indifference and the intractable miseries to which these lead' (Mills, 2000: 17-18). Although Mills subsequently qualifies these remarks by saying people 'often' do not find in fiction and journalism the qualities that generate a 'big picture', suggesting that such writing may sometimes offer such a picture, it is social science informed by the sociological imagination which he sees as providing 'intellectual and cultural aid' to serious artists, rather than the other way round (Mills, 2000: 17-18). In other words, Mills seems to believe that speculative literature can only imperfectly realise the sociological imagination and that it can only begin to do so when supplemented by empirical social science.

On the other hand, when explaining how contemporary social science can help us understand the relationship between the course of history and the transformation of human nature, Mills pointedly lists George Orwell's Nineteen Eighty-Four (1949) alongside such social-theoretical classics as Georg Simmel's The Metropolis and Mental Life (1903) and Karl Marx's early writings, and such contemporary sociological studies as David Riesman's research on 'other-directed' cultures and William H. Whyte's writings on the 'social ethic', as a work that illustrates and examines the modern 'advent of the alienated man' (Mills, 2000: 171-72). As such, one can understand why subsequent scholars working on the sociological imagination have argued that literary works themselves are able to provide sociologically relevant insights. For instance, in his thought-provoking essay, 'The Literary Imagination and the Sociological Imagination', Richard Hoggart proposes that, rather than simply illustrating "that " $\mathrm{X}$ " is what a society believes, assumes, [and] feels', literary evidence 'recreates what it seems like to be a human being or a society which believes, assumes, or feels "X" (Hoggart, 1970: 270). At their best, the writer and the social scientist are 'close to each other' because the latter's 'capacity to find hypotheses is decided by [their] imaginative power' (Hoggart, 1970: 265). Literature can therefore benefit sociology because it can improve the sociologist's 'sense of perspective', and 'because its ideas and images often anticipate many 
sociological theories and observations and therefore can be of...great service for hypothesis and provisional orientations' (Mistzal, 2016: 318).

Accordingly, taking the work of Wells, Mills, and Hoggart as points of departure, the present essay argues that investigating the connection between dystopian fiction and the sociological imagination builds upon and potentially enhances Mills' original employment of this concept. It does so by demonstrating how constructing and analysing social worlds that 'might be' is itself a potent exercise of the sociological imagination, and how such exercises of the sociological imagination can aid the work of professional sociologists. The essay further argues that, within the broad genre of speculative literature, dystopian fiction ought to be of particular interest to sociologists for two related reasons. First, the speculation in dystopian fiction tends to be more grounded in empirical social reality than in the case of utopian fiction. Second, compared to those of the utopia, the literary conventions of the dystopia more readily illustrate the relationship between the inner life of the individual and the greater whole of social-historical reality: in other words, dystopian fiction is especially attuned to the interplay of 'biography and history' described by Mills. For both these reasons, dystopian fiction is situated somewhere between the subjective and objective poles, allowing it to illustrate how personal experience and social structure enter into and mutually influence one another with a phenomenological richness unmatched by empirical analysis.

It is worth emphasising that this exploration of the link between dystopian fiction and the sociological imagination, and of the question of why this link makes the dystopia more helpful to sociologists than previously realised, is distinct from existing explorations of speculative literature's pedagogical value in sociology. There is in fact a vein of scholarship on the topic of how fiction can aid the sociological imagination in the classroom, often by assigning students to analyse existing works of speculative literature or to write their own in order to understand the place of characters' individual lives and choices within the context of social institutions and systems. While both scholarly endeavours show a certain appreciation for how speculative literature can aid sociological thinking, the pedagogical use of speculative literature differs from the current project because it treats speculative literature as something more akin to a 'training ground' for inexperienced sociologists before they proceed to 'real' sociological enquiry. Contrastingly, in this article we seek both to rectify the neglect of the speculative dimension in sociological enquiry itself and to revive the notion of speculative literature as a form of sociology in its own right. That said, our analysis of dystopian fiction as a significant exercise of the sociological imagination will almost certainly be of interest to those researching the pedagogical value of speculative literature as it offers a novel account of why a specific subgenre of speculative literature might be especially conducive to thinking sociologically.

\section{Utopia, anti-utopia, and dystopia}


A first question to consider about existing engagements with speculative literature on the part of sociologists is that of why dystopias have historically received far less attention than utopias. As we have seen, utopia, both as an analytic category and as a literary subgenre, has been the subject of considerable attention from a number of prominent social thinkers, including within the discipline of sociology itself. References to dystopia, on the other hand, are far less common, tending to be confined to footnotes, incidental allusions, or casual remarks. Where dystopia is addressed, it is generally by way of contrast with utopia in order to bring the outline of the latter more clearly into view, rather than as a distinct topic meriting sociological consideration in its own right. In her major study of the relevance of utopia to sociology, Utopia as Method, for example, Levitas devotes less than a page to dystopia, acknowledging the potential of the dystopia to function as 'a vehicle of resistance' while holding it to be 'less able to register transformation' than the utopia (Levitas, 2013: 111).

One prominent sociologist who has occasionally drawn on dystopian literature in his analysis of modern society is Zygmunt Bauman. Three of Bauman's works, in particular, are pertinent to a discussion of the significance of dystopia for the sociological imagination: Modernity and the Holocaust, Liquid Modernity, and Retrotopia, each of which resonates in a number of ways with the recurring concerns and anxieties of dystopian literature in the twentieth century. In Modernity and the Holocaust, Bauman calls modern discourses of progress into question and explores how some of the defining features of modern society - including bureaucracy, industrialisation, social engineering, and scientific rationality - were simultaneously the preconditions for dehumanisation and mass extermination on an unparalleled scale. Although the category of utopia is only intermittently invoked in the book, Modernity and the Holocaust may be read as an implicit critique of the major utopian projects of the twentieth century, and of their ambition to remake humanity in particular. Like the major dystopian novels of the first half of the century, then, Bauman's book is an indictment of the course taken by modernity and of the gulf between its aspirations and its realisation in practice. With the exception of an epigraph from Orwell and an incidental reference to Kafka (Bauman $2000,137)$, however, the book does not at any point draw directly on dystopian literature, even if dystopian 'echoes' may be heard throughout some of its main arguments.

Similar observations may be made of Retrotopia, a much more recent work, in which Bauman assesses the status of utopia in the early decades of the twenty-first century. In the course of a subtle and ingenious argument, Bauman shows how the longing for utopia has come to be directed backwards, towards the past, and away from the future it had taken as its target throughout the modern period (Bauman 2017, 1-12). On this account, the utopian impulse has by no means withered away or vanished but has been powerfully reinvested in versions of an idealised past, including unified images of the nation state (Bauman 2017, 60-85). While utopia served to negate the present in order to imagine a better future, retrotopia constitutes what Bauman calls a 'negation of utopia's negation' ((Bauman 2017, 8), that is, a utopian negation of modern utopia in order to imagine a better past. As in the case of Modernity and the Holocaust, the dystopian tenor of Retrotopia does not extend to an engagement with dystopian literature, even if Bauman's pessimistic social analysis approximates dystopian fiction at points. While noting the dystopian turn taken by contemporary culture - 'our sci-fi films and 
novels are more and more often catalogued in the sections of horror movies and gothic literature' (Bauman 2017, 58) - and acknowledging the prescience of literary figures such as Kafka (Bauman 2017, 4) and Orwell (Bauman 2017, 11), Bauman does not engage in fuller analysis of any specific dystopian texts. Like Mills, however, it is clear that Bauman considers such literature to be something which would repay serious sociological consideration, as when he remarks in a suggestive footnote that J. G. Ballard's dystopian novel Kingdom Come (Ballard 2014) offers 'a most brilliant presentation' of some of the issues around contemporary consumer culture (Bauman 2017, 170).

Of the three works, it is Liquid Modernity, however, which has the most to say directly about dystopian literature. Among the many commentators on modernity discussed by Bauman, both Orwell and Huxley feature at several key points, and are treated on the same terms as theorists such as Marx, Weber, or Adorno. In this respect, Bauman is unusual among sociologists in the high status he accords to literature. Bauman describes Orwell's Nineteen Eighty-Four as an 'inventory of the fears and apprehensions which haunted modernity during its heavy stage' (Bauman 2000, 26), and later claims that Huxley's Brave New World may be read in the same way (Bauman 2000, 53). What Orwell and Huxley shared, Bauman observes, was 'the foreboding of a tightly controlled world' (Bauman 2000, 53), in which conformism and routine had triumphed over individual freedom. The contention of Bauman's analysis of Orwell and Huxley, however, is that the historical conditions in which their foreboding was articulated no longer exist, meaning that Orwell and Huxley's dystopias may now be seen as expressions of a very specific moment in the history of capitalism (Bauman 2000, 5355). The transition to liquid modernity - encompassing such developments as globalisation, financialisation, the preponderance of information technology, and the increasing fluidity of social identity - means that the Fordist mode of production which, on Bauman's view, structures both Orwell and Huxley's fictions, has long since been left behind and exchanged for a hyper-individualistic society of a very different kind (Bauman 2000, 56-64). The implication of Bauman's discussion of dystopia is thus that dystopian literature, at least in its most familiar form, was a literary product of 'heavy' capitalism and hence, from our contemporary perspective, of a bygone era. In conclusion, two provisional points may be made about Bauman's engagement with Orwell and Huxley. The first is that, despite being confined to just a few pages of a much longer study, Bauman's analysis hints at some of the rich possibilities of a sociological engagement with dystopian literature. The second is that, in light of Bauman's apparent consignment of dystopia to the past, a question that might repay consideration is that of what more recent dystopias might be able to teach us about the nature of liquid modernity.

In thinking about what accounts for the lack of interest in dystopia among sociologists, it may be helpful to pose a more basic question about the nature of dystopia. This will be especially true if, as we suggest, a lack of understanding of dystopia on the part of sociologists lies at the root of the neglect of dystopia within the social sciences. How, we may ask, is dystopia to be defined, and how is it distinguished from utopia? The answer to this question may appear obvious. One immediate response would be to cite the commonplace definitions of the two terms: a utopia is a (very) good place; a dystopia 
is a (very) bad place. This answer, although correct as far as it goes, is of limited use for our current purposes, as it tells us very little about the relationship of dystopian fiction to the sociological imagination. While it may make a kind of intuitive sense to say that imaginative portrayals of (very) bad places could be useful to people who study society, we will need a fuller and more detailed account of why this is the case if we are to persuade the working sociologist to devote time and energy to studying dystopias. This will involve saying more about what dystopia is, how it functions, and how it differs from utopia.

Social theorists from Wells to Levitas have taken utopia as one of their core concerns and highlighted its relevance to the pursuit of the social sciences. The treatment of utopia at the hands of these theorists has often proven insightful, nuanced, and productive. The category of dystopia, on the other hand, has tended to be handled less adroitly. One likely reason for this is that many theorists have tended to endorse the equation of dystopia with anti-utopia, as in the case of Kumar's comprehensive study, Utopia and Anti-Utopia in Modern Times, a decisive intervention that has to a considerable extent set the parameters for sociological enquiry into utopia ever since (Kumar, 1987). Kumar is very clear about this identification in the opening pages of his book, where he defines the anti-utopia - a term he uses in place of the term 'dystopia' as 'a relatively recent invention, a reaction largely to the socialist utopia of the nineteenth century and certain socialist practices in the twentieth century' (Kumar, 1987: viii). Complicating matters somewhat, there is the further fact that this habit of equating dystopia with anti-utopia is shared by a number of prominent literary scholars who have written on utopia, most notably Fredric Jameson in his much-cited book, Archaeologies of the Future (Jameson, 2005).

An anti-utopia may be defined as a depiction of a society in which an attempt to realise a utopian project has been made but where the results of this project have proven disastrous or catastrophic or oppressive in some notable respect. The precedent for the anti-utopia is arguably Jonathan's Swift's Gulliver's Travels (1726), which depicts several societies - such as the kingdom of Balnibarbi, where the state's resources are lavished on absurd pseudo-scientific research projects while many citizens are forced to go without food - in which attempts to realise utopian dreams have produced grotesque or inhuman outcomes. Meanwhile, Aldous Huxley's Brave New World (1932) is perhaps the clearest example of the anti-utopia in twentieth-century fiction. Huxley's World State is, on one level, a fully realised utopia, in which material scarcity and want have been wholly eliminated. On a second level, however, the World State functions as a powerful illustration of the potential for technologically advanced, sexually liberated consumer societies to impose an unprecedented degree of conformity and social control. A third major example of the modern anti-utopia is Arthur Koestler's Darkness at Noon (1940), a thinly disguised portrayal and excoriating critique of Soviet communism in general and Stalinist Russia in particular. Koestler's novel is an anti-utopia in that it serves as both an indictment of a particular society and as a more general comment on any attempt to realise grand utopian plans without regard to their more local human consequences. While there are many other influential examples of the anti-utopia which could be cited, Gulliver's Travels, Brave New World, and Darkness at Noon may stand as three exemplary instances of this almost three-hundred-year-old literary tradition. 
Despite the classic status of these three anti-utopian novels, however, it is important to note that fiction of this type is by no means the only kind of dystopian literature that exists. Other varieties of dystopia, some of which serve very different purposes to that of the anti-utopia, have been and continue to be written. Not all dystopian literature is designed to convey a warning about the limits of utopian planning or the hubris of promethean projects of world transformation. In equating dystopia with anti-utopia, as opposed to treating the anti-utopia as merely one form of dystopia, writers like Kumar and Jameson may be seen to endorse a quite constricting view of the subgenre as one whose primary if not sole purpose is to oppose the utopian impulse in modern social thought. Despite making a limited concession to the possibility of alternative styles of dystopia, Jameson, for instance, claims that in decisive cases such as Animal Farm (1945) and Nineteen Eighty-Four, dystopia springs from 'a conviction about human nature itself, whose corruption and lust for power are inevitable, and not to be remedied by new social measures or programs' (Jameson, 2005: 198).

This is, to be sure, one of the things authors of dystopias have used their fictions to accomplish, but it is far from the only one. Levitas, one of the few sociologically oriented commentators to pick up on this point, briefly acknowledges that dystopias are 'not necessarily anti-utopian', but then goes on to limit the scope of dystopia in a different way by assigning it just two, seemingly mutually exclusive options: namely, 'whether the dystopia points to an unremitting closure or to another possible future' (Levitas, 2013: 110). While this way of parsing the possibilities of dystopia is helpful up to a point and has yielded some important insights - most notably in the work of the utopian scholar Tom Moylan (Moylan, 2018) - it by no means exhausts the critical and imaginative potential of this form of literature. Moylan, for instance, provides a fascinating account of what he calls 'critical dystopias': texts which are said to 'linger in the terrors of the present even as they exemplify what is needed to transform it', thereby retaining a utopian impulse in the face of the bleakest dystopian scenarios (Moylan, 2018: 198-199). Even Moylan's concept of the critical dystopia has, however, been used by other theorists to police the boundaries of the dystopian subgenre, with Jameson, for example, suggesting that only fictions which fall within the purview of Moylan's theory ought to be termed 'dystopias', whereas all other ostensible dystopias are in fact antiutopias (Jameson, 2005: 198-99). Allowing for the sole exception which Jameson makes in the case of the critical dystopia, then, Kumar's influential identification of dystopia with anti-utopia may be seen to be still in force in recent social and cultural theory.

\section{Varieties of dystopia}

Despite this quite widespread tendency to homogenise dystopia, the dystopian subgenre reveals itself on closer inspection to be fairly diverse - certainly more diverse than many theorists have tended to allow for. Relevant here is Gregory Claeys's tripartite distinction between political, environmental, and technological dystopias, and his accompanying observation that, "it is the totalitarian political dystopia which is chiefly associated with 
the failure of utopian aspirations, and which has received the greatest historical attention' (Claeys, 2017: 5). While dystopias have often advanced an anti-utopian agenda, they need not necessarily do so. Over against the longstanding tendency to equate dystopia with anti-utopia, another notable role played by dystopian fiction is to imagine the likely consequences of existing social patterns and trends. Dystopias of this sort, which we may call 'extrapolative' dystopias, work by identifying something already taking place in society and then employing the resources of imaginative literature to extrapolate to some conceivable, though not inevitable, future state of affairs.

Acclaimed recent examples of extrapolative dystopias include Dave Eggers' The Circle (Eggers, 2013) and Lidia Yuknavitch's The Book of Joan (Yuknavitch, 2017). In Eggers' The Circle, the undermining of democratic norms and forms of government by today's tech giants is taken to its logical conclusion as The Circle, an organisation bearing a close resemblance to Google, displaces the US government and inaugurates a form of 'soft' totalitarianism through digital technologies and 24/7 'transparent' surveillance. In Yuknavitch's The Book of Joan, global warming and an ensuing ecological domino effect have culminated in an event referred to as the 'geocatastrophe', which has rendered the earth largely uninhabitable, forcing the few survivors who can afford to do so to take up residence in 'suborbital complexes' under the control of the celebrity-turned-dictator Jean de Men. In both novels, social phenomena with which we are already familiar - industrial monopolies, data harvesting, digital surveillance, the manipulation of mass opinion, anthropogenic climate change, species extinction, rightwing populism, resource scarcity, and global inequality - are taken as the starting points for extrapolations to future or near-future scenarios which are both remote from our own moment yet unnervingly close to it at the same time. This uncanny double positioning, whereby a world which initially strikes us as alien is shown to be largely implicit in the world we already inhabit, is the central tenet of the extrapolative dystopia, as well as one of the keys to its sociological relevance

The relation of the extrapolative dystopia to the category of utopia is highly variable, and is for this reason perhaps best gauged on a case-by-case basis. The Circle, for instance, is in part an anti-utopia: the vision of the perfectly 'transparent' society projected by the so-called Three Wise Men who direct The Circle is clearly signposted as utopian, with unmistakable echoes of spokesmen for earlier anti-utopias such as Wells's Dr Moreau, Yevgeny Zamyatin's Benefactor, and Huxley's Mustapha Mond. In Yuknavitch's The Book of Joan, on the other hand, this anti-utopian element is less central. While reference is made at points to Jean de Men's dream of a technologically 'improved' humanity built according to his own specifications, this utopian subplot is largely subordinated to the novel's engagement with a range of other themes such as the environment, gender, and religion. It is noteworthy, furthermore, that the story takes place within a social and political context which, as the novel makes clear, was already decidedly dystopian prior to the rise of de Men himself. The Book of Joan is perhaps best characterised, then, as an extrapolative dystopia with anti-utopian elements.

A third case worth considering in this connection is that of the dystopia envisaged by William Gibson and given its definitive formulation in his cult cyberpunk novel Neuromancer (Gibson, 1984). The society depicted in this novel is clearly signposted as a 
dystopia, but there is no suggestion that this state of affairs is the result of an attempt to construct a 'perfect' world or ensure universal happiness. Rather, the alienated condition of its inhabitants is the side-effect of long-term social patterns of monopolisation, corporate dominance, and general disregard for the natural environment under late capitalism, all of which are shown to reach down into and penetrate the most intimate aspects of the life of the novel's protagonist, Henry Case. Whereas in the anti-utopian Brave New World, every aspect of human life is precisely calibrated and controlled in order to maintain stability and conformity, in Neuromancer it is more the case that the majority of the population scarcely enter into the planning decisions of the all-powerful corporate elite. To this extent, Neuromancer could possibly be regarded as a limit case of the anti-utopia, for while the ' $1 \%$ ' may regard such a world as in some sense a utopia, albeit one confined to their own private enclaves, from the point of view of the vast majority, including anyone concerned with social justice, quality of life, or the fate of the planet, Gibson's novel is one of the most disconcertingly plausible depictions we have of a dystopian society extrapolated from existing social and economic trends.

Other dystopias, meanwhile, depart entirely from the template of the anti-utopia. Rather than being concerned with the failure of utopia, these fictions take as their focus all manner of other social pathologies. Margaret Atwood's The Handmaid's Tale (Atwood, 1985) is a case in point. Through a series of ingeniously structured flashbacks, the Republic of Gilead - the authoritarian, theocratic regime which has ousted the U.S. government in the novel - is shown to be the product of longstanding resentments and grievances present throughout American society, as well as a desperate reassertion of authority in the face of social insecurity and global conflict. As in the case of Orwell's Oceania, Gilead originates as a pragmatic response to an unforeseen series of crises, not as an attempt to engineer a perfect society. The religious justification which is given for the social hierarchy and strictly enforced gender roles of Gilead is, as Atwood has herself observed, an ideological mystification of prevailing material conditions, including a severe fertility crisis. Like the elite which has risen to power in Yuknavitch's The Book of Joan, the upper-class members of Gilead are not so much fanatical ideologues wedded to their sacred cause as they are a group of people prepared to make use of any means necessary to hold onto and reassert their respective privileges in the face of the breakdown of established social structures, ways of life, and forms of belonging.

Another illustrative case of the dystopia which is not an anti-utopia is provided by Octavia Butler's Parable trilogy: Parable of the Sower (Butler, 1993), Parable of the Talents (Butler, 1998), and the never completed Parable of the Trickster. These novels are set in a near-future America in which a combination of corporate dominance, government corruption, widespread poverty, gang warfare, environmental degradation, and general social breakdown have brought the country to the verge of collapse. Poorer citizens are left to fend for themselves with minimal support from police or other state services, while the slightly more affluent take refuge in small gated communities. Even the latter are at constant risk of attack, however, as the protagonist of the series, Lauren Olamina, discovers when her family's inadequately fortified compound is stormed and burnt to the ground near the beginning of the first novel. Like Atwood's Gilead, Butler's dystopian America is firmly grounded in empirical reality. While the Parable series is in some respects a work of science fiction - the unwritten third instalment was to be 
concerned with the terraforming of Mars - none of the social, political, or economic factors which motivate the plot of the first two novels is invented, enabling Butler to searchingly interrogate the real present in the context of a fictional future. Indeed, much of the force of Butler's work arguably arises from the way it depicts something more like a near-apocalyptic perfect storm of familiar tendencies within American society, rather than an attempt to imagine something radically new.

The roots of the chaotic, antagonistic, almost lawless society inhabited by Olamina are indicated implicitly via her exchanges with a variety of characters, as well as via suggestive background details inserted throughout the novels. These factors are shown to include class divisions and structural inequality, racism and white supremacy, gender inequality, the aggressive reassertion of 'traditional' values in the face of uncertainty about the future, religious fundamentalism, gun ownership and a frontier mentality, patterns of precarious work and high unemployment, and a lack of concern for the environment and climate change denial. Some of these - such as gun ownership and white supremacy - can be traced all the way back to America's founding. Others - such as high unemployment and climate change denial - are more recent developments associated with a later phase of capitalism. What Butler has done in the Parable series is to give these familiar social phenomena a prophetic nudge in the direction of a world to which, taken altogether, these diverse tendencies could conceivably give rise.

The one clear departure which Butler does make from existing reality is to envision something like the institution of slavery returning to the U.S. In Butler's America, privatisation has increased rapidly, workers' rights and union activity have been entirely suspended, and legal restrictions on corporate behaviour have been relaxed even beyond those which existed at the time of the novels' composition in the 1990s. Given the high level of unemployment afflicting the U.S. economy in the books, citizens have no choice but to take work where they can find it - up to and including becoming the voluntary slaves of the all-powerful corporate juggernauts who are now America's de facto rulers. In return for meagre wages, rudimentary accommodation, and a measure of protection from the violent world outside, the new hyper-corporations demand total loyalty and exhausting labour from those who flock to them. Even here, however, Butler is arguably only taking a small speculative step beyond the neoliberal settlement prevailing in her own moment. It is not implausible to suggest that one likely consequence of shrinking the state and drastically minimising government expenditure on public services will be to leave citizens vulnerable to exploitation by private interests and increasingly dependent for their welfare on corporations whose only real interest is the profit motive. Indeed, since the Parable series was published, these real-world tendencies have been observed to an increasing extent, both within the U.S. and in other countries where the neoliberal economic model has been adopted.

The virtue of Butler's dystopian reimagining of neoliberal America is to explore, concretely and dramatically, how the indefinite extension of this economic logic could play out both at the macro level of society as a whole and at the micro level of the lived experience of individual people, such as Lauren Olamina and her allies. To this extent, the Parable novels, like other comparable extrapolative dystopias, function somewhat like the thought experiments employed by philosophers, with the crucial difference that, 
rather than quickly sketching a scenario in its bare lineaments before proceeding directly to its philosophical - or, in this case, sociological - consequences, novels like Butler's focus primarily on world-building, that is, on providing the richest, fullest, most completely imagined version they can of the social circumstances informing the events they describe. Paradoxically, it is precisely by refusing to rush to the sociological pay-off of such world-building that extrapolative dystopias, and dystopias more generally, attain their full sociological significance. The difference between a six-thousand-word academic article about the future of neoliberalism and a seven-hundred-page series of novels portraying that future is more than merely quantitative. This difference may be cashed out in terms of Mill's concept of the sociological imagination: what fiction does which empirical analysis cannot do is to bring social structure (the 'objective') and individual experience (the 'subjective') together in a way which shows how the two enter and mutually influence one another. Dystopian fiction is thus situated neither at the level of law-bound scientific prediction nor at the level of wholly idiosyncratic private experience, but somewhere between the two.

\section{Dystopia and the question of perspective}

Our argument so far at this point brings us to a noteworthy difference between utopia and dystopia, one with important implications for the sociological significance and applications of the latter. Generally speaking and for the most part, utopias adhere to a generic convention whereby they adopt the perspective of a visitor or outsider figure. In Thomas More's Utopia (1516), Edward Bellamy's Looking Backward (1888), and William Morris's News from Nowhere (1890), for example, what is offered is in effect a 'guided tour' of a utopian society, rather than a dramatic narrative populated by richly developed characters and varied plot developments. The protagonists in these texts are thinly drawn, tending to be little more than means for the reader to learn about how the utopia functions and to gain an overview of the social totality. Dystopia, by contrast, is almost always described from an inhabitant's perspective. Orwell's Nineteen EightyFour, Atwood's The Handmaid's Tale, Butler's Parable novels, Egger's The Circle, and Yuknavitch's The Book of Joan all illustrate this point well. In each case, the dystopia is seen from the point of view of someone living under the regime in question and whose subjectivity has been shaped by that form of life, rather than by a 'tourist' from a distant time or place.

This is a key distinction and one which helps to account for the unique contribution dystopia is able to make to the sociological imagination. More's Utopia is, of course, an early modern political satire rather than a work of modern fiction, and so it would be somewhat anachronistic to expect it to incorporate the full arsenal of modern literary techniques. In the case of Bellamy's Looking Backward and Morris's News from Nowhere, however, and indeed even in the case of much more recent utopias such as B. F. Skinner's Walden Two (1948) and Ernest Callenbach's Ecotopia (1975), a similar manner of narration persists. These texts are all much more like blueprints, finely drawn 
outlines of ideal societies, than they are like dramatic accounts of historically existing individuals living out their lives. There are various reasons for the 'blueprint' format and 'tourist' style of narration within utopian fiction, all of which have been thoroughly explored by literary scholars in the field. Admittedly, this picture is complicated by the existence of what Moylan has termed the 'critical utopia', a form of literary utopia which arose out of the cultural and political upheavals of the 1960s and 70s (Moylan, 2014). These utopias - by authors such as Ursula Le Guin, Marge Piercy, and Sally Miller Gearhart - are noticeably less like blueprints than their predecessors, and, as Levitas rightly notes, place greater emphasis on subjects and political agency (Levitas, 2013: 110). With the exception of Levitas herself, however, and despite its noteworthy contribution to the utopian literary tradition, the critical utopia has, like the dystopia, so far received very little attention from sociologists, despite a substantial body of work on the topic within literary studies.

Although the present essay's focus on dystopian fiction means that a specifically sociological consideration of critical utopias will have to be set aside for now, even with the complications the critical utopia introduces, the point stands that Orwell's Winston Smith, Atwood's Offred, Butler's Lauren Olamina, Eggers' Mae Holland, and Yuknavitch's Christine are all characters in a much fuller sense than the protagonists of the utopian texts which have so far received attention within the discipline of sociology. Significantly, these characters achieve this fullness because they are notably more reflective than their utopian counterparts, both about their own experiences and about the wider changes undergone by their respective societies. All five characters engage in critical reflection on the developments which have led to the dystopian condition in which they find themselves, and are highly aware of how those developments have impacted and continue to impact their lived experience. Even early examples of dystopian fiction that seem, at a first glance, to share the classic utopia's 'tourist' perspective turn out, on closer inspection, to subvert this convention. When the timetravelling protagonist of Wells's The Time Machine (1895) tells the narrator of the story about the society he has visited, the account he initially offers is schematic and 'thin', like that of the portrait of Utopia painted by More's Raphael Hythloday. It is only as he becomes more immersed in that society that its more disturbing elements come to light and begin to be rendered by Wells in 'thicker', more experiential terms: in particular, the emptiness of the Eloi's hedonism, the brutish existence of the subterranean Morlocks, and the inequality pertaining between the two groups. In other words, it is as he makes the transition from detached observer to involved inhabitant that the Time Traveller becomes aware of the true nature of this apparent paradise, and begins to speculate as to how this state of affairs could have arisen from the class divisions of his native Victorian England. All this points, once again, to what makes the exercise of the sociological imagination in dystopia so potent: its imaginative exploration of a possible world which we are able to recognise as grounded in or extrapolated from selected features of present social conditions.

\section{Sociology and dystopia}


In light of the foregoing analysis, we submit that exploring the connection between dystopian fiction and the sociological imagination builds upon and enhances our understanding of the latter concept, such that professional sociologists would benefit from taking dystopian fiction far more seriously than heretofore. Central to this contention is the fact that, as we have seen, the protagonists of such fiction tend to be more fully developed characters than those in utopian fiction, and, crucially, are more conscious of how social and historical developments have shaped and continue to shape their lives, allowing them to situate and comprehend their individual existences within a much broader socio-historical picture. In this way, dystopian fiction exemplifies the virtues of Mills' sociological imagination on two distinct levels: firstly, by employing literary characters to, in Mills' words, 'understand the larger historical scene in terms of its meaning for the inner life and external career of a variety of individuals' (Mills, 2000: 5 ), and, secondly, by cultivating this understanding in readers by using fiction to extrapolate from events and patterns in the real world, thereby making them more fully aware of how 'the individual can understand his [sic] own experience and gauge his own fate only by locating himself within his period...' (Mills, 2000: 5). In short, dystopian fiction is notably adept at drawing the connections between private troubles and public issues that Mills considered fundamental to sociological thinking: like the best works of sociology in the conventional sense, dystopian fiction helps us envisage the relationship between biography and history.

A further reason for dystopian fiction's ability to connect the private with the public, or the biographical with the historical, is its distinctive positioning between the subjective and objective poles - that is, its ability to show how elements of social structure and individual experience influence each other, thereby capturing how it feels to inhabit a particular social world with a vividness that even a qualitative ethnography that strives for the 'thickest' description can arguably never quite achieve. One could thus understand dystopian fiction as a bridge between the phenomenology and the historicity of social being. Taking this view of dystopian fiction helps us reinterpret the relationship between empirical research and speculative literature within sociology in a manner that is in very much in the spirit of Mills, but which counters what we saw to be Mills' own ambivalence towards literary fiction. Rather than seeing speculative literature as only having sociological value when supplemented by empirical social science, one could see it as extrapolating from empirical observations of present conditions in a manner which is fully consonant with the aims of sociology.

With this in mind, it is easier to understand how writers of dystopian fiction have often been able to move from more speculative to more straightforwardly political commentaries on the social issues of their day. For instance, nearly thirty years after Brave New World, Huxley wrote Brave New World Revisited (1958), a work of nonfiction in which he reflects on such matters as the threat of subliminal suggestion to democracy and the risk of human overpopulation. Huxley did so in part by drawing on his fictional works, considering whether humanity was moving further from or closer to the future he envisaged in Brave New World. This move from dystopian speculation to direct social commentary suggests that dystopian fiction provides constructive grounds for real-world social and political interventions. Indeed, the real-world developments that dystopian fiction typically portrays, such as ecological destruction, mass consumerism, 
and religious fundamentalism, have been and remain very much at the centre of modern political debates. In identifying possible outcomes of observable social trends rooted in human collective action, dystopian fiction implies that we may be able to intervene to prevent such outcomes. This resonates strongly with Mills' own view that sociologists are duty-bound to help members of wider society understand the intersection between their private troubles and public issues, and Mills' personal practice of writing pamphlets for public engagement alongside his academic works. As Mills put it in his autobiographical Letters to Tovarich, 'the good writer tries to unite a variety of private lives with public affairs', and 'to enrich the private by making it publicly relevant' (Mills and Mills 2000: 280). Interestingly, the 'Tovarich' to whom these letters are addressed is a fictional Soviet intellectual. In other words, whatever ambivalence Mills expressed about the ability of fiction to stimulate the sociological imagination, there is at least one instance of Mills himself using a kind of fictional writing to make a point about sociological practice.

We may conclude by observing a suggestive resonance with sociology's roots in German social thought. Compared to philosophers in the Anglo-American canon, German philosophers and social thinkers as diverse as Hegel, Marx, Weber, Simmel, Heidegger, and Arendt tend to be highly conscious of philosophy's own historicity. In other words, many of the theorists considered canonical within sociology are located in a philosophical tradition that tries to understand and places an emphasis on the historically embedded condition of humanity, and of the very act of theorising itself. Dystopian fiction aligns with this tendency insofar as it attempts to capture and imaginatively convey how certain forms of human subjectivity emerge from and respond to specific historical conditions. Regrettably, a thorough exploration of either the implications of dystopian fiction for the interventionist potential of sociology, or of its relationship to the social-theoretical traditions in which sociology is partly rooted, lies beyond the remit of this essay. Nevertheless, it is clear that a reappraisal of dystopia is long overdue in discussions of the speculative within the social sciences and within the discipline of sociology in particular.

\section{References}

Atwood M (1985) The Handmaid's Tale. Toronto, ON: McClelland \& Stewart.

Ballard J G (2014) London: Fourth Estate.

Bauman Z (2000) Liquid Modernity. Cambridge: Polity.

Bauman Z (2000) Modernity and the Holocaust. Cambridge: Polity. 
Bauman Z (2017) Retrotopia. Cambridge: Polity.

Bell D (2017) Pragmatic Utopianism and Race. Modern Intellectual History. Epub ahead of print 23 November 2017. DOI:10.1017/S1479244317000555.

Brewer JD (2005) The Public and Private in C. Wright Mills's Life and Work. Sociology 39(4): 661-677

Claeys G (2017) Dystopia: A Natural History. Oxford: Oxford University Press.

Eggers D (2014) The Circle. London: Penguin.

Gibson W (1984) Neuromancer. New York: Ace Books.

Hoggart R (1970) The Literary Imagination and the Sociological Imagination. Speaking to Each Other: About Society Vol. 2. London: Chatto \& Windus.

Jameson F (2005) Archaeologies of the Future. London: Verso.

Kumar K (1987) Utopia and Anti-Utopia in Modern Times. London: Blackwell.

Kumar K (1990) Wells and "the So-Called Science of Sociology". In: Parrinder P and Rolfe C (eds) HG Wells Under Revision Proceedings of the International H.G. Wells Symposium, London, July 1986. London and Toronto: Associated University Presses, pp. 192-217.

Levitas R (2010) Back to the future: Wells, sociology, utopia and method. The Sociological Review 58(4): 530-547.

Levitas R (2013) Utopia as Method: The Imaginary Reconstitution of Society. New York: Palgrave.

Mills CW (2000) The Sociological Imagination. New York: Oxford University Press. 
Mills K and Mills P (2000) C Wright Mills: Letters and Autobiographical Writings. Berkeley: University of California Press.

Mistzal BA (2016) Sociological Imagination and Literary Intuition. Comparative Sociology 15: 300-323.

Moylan T (2014) Demand the Impossible: Science Fiction and the Utopian Imagination. Bern, CH: Peter Lang.

Moylan T (2018) Scraps of The Untainted Sky: Science Fiction, Utopia, Dystopia. New York: Routledge.

Wells HG (1907) The So-Called Science of Sociology. Sociological Papers 3: 357-369.

Yuknavitch L (2017) The Book of Joan. London: Canongate. 